\title{
The Role of Medias in Tools Lesson about Environmental Education in Distance Education System (Iran)
}

\author{
Elham Koohi ${ }^{1}$, Seyed Mohammad Shobeiri ${ }^{2}$ Mohammad Zakaria Kiaei ${ }^{3}$, \\ Hossein Meiboudi* ${ }^{4}$

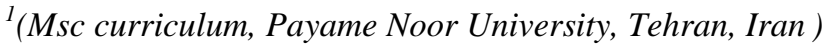 \\ ${ }^{2}$ (Associate professor, Department of Environmental Education, Payame Noor University Tehran, Iran) \\ ${ }^{3}$ Instructor at Qazvin University of Medical Science Branch, Qazvin, Iran) \\ ${ }^{4}$ Ph.D Student of Environmental Management, IAU, Science and Research Branch, Tehran, Iran)
}

\begin{abstract}
The express development of internet and branches of multi medias in world wide channel, have created the new method for transfering the information to the students. Doubtless, timing education is the most effective method of education by face to face connection. But greatness of distance and shortage of time has limited the chance of participation of students in this kind of classes. This study had done with the goal of comparative investigation about the rate of effectiveness in teaching of procurement and production of materials and progressive tools lesson in environmental field in 2 groups of students of virtual and conventional study that did on 2 groups of students in each group we had 30 final semester students in environmental field in Payam noor university, Tehran virtual group trained the procurement and production of material and progressive tools about environmental education in the first semester of 2011-12 and face to face group trained it face to face. At the end of educational course, both groups evaluated in a same situation and same examinable materials. The required information analysised by the descriptive and perceptive statistic. Also the average of

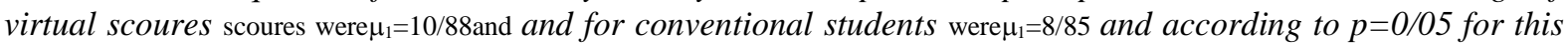
kind of students, so we can conclud that there is a specific different between these groups. As a result you can train procurement and production of materials and progressive tools lesson about environmental education by the distance education method and it doesnot have any educational grade reduction.
\end{abstract}

Keywords: Medias, Distance education, Conventional education, Environmental education Iran

\section{INTRODUCTION}

This in the recent decade, conventional procedares of learning has exposed to change with appearance of new technologies such as multi medias or extra medias or distance education and communication. some factors such as progressive technology, increasement of population, economic problems, geographical distribution in some countries, request for more education and tendancy to self study or improvement in education, its name is distance education ${ }^{[1]}$.

In the recent years . some universitys like Tehran ,Amir kabir, Elmosanat universitys are using the different methods of distance education just because of some problems that the young people have in our country such as enterance exam and limitation in state facilities, so using the entrance education and electronic education is the suitable method.During these years, unfortunatly Azad university has stayed back ward about this subject, so we should stress that if you want to connect to daily and on line information in world ,attendants should attend to suitable mechanism on account of institutionalize the distance education, in recent education and parallel with face to face education, because inattention toward basic paradimes change in university education in the world based on distance and electronic education and effected by achivements of information and relation technology cause to boycott and stay back ward of educated and Academicsociety and hage courses in the main intelligence services in the information and communication age ${ }^{[2] .}$

You can use distance education that teacher and students are for from each other and their connections are possible with using the medias and different technologys such as (copy,telephon, radio, tv, computer) .

Vsing these medias can be effective and act as a bridge for filling the distance of them. The historical move ment of this education has kept stay with production or medias change of transfering the information.

Madias act as a tool that cause to creat the relation between (messenger/ teacher and learner/ student). For correct usage of medias need necessary information about options and technique of applications. This information leads you to reach the main goad of teaching, means transfering and better themes understanding . necessity and importance of it in distance education system is more just because of absence of students beside the teacher in learning procedure. The usage of distance education style had seen with exploitation of medias (mass and aducational) in different field ${ }^{[3] .}$ 
Today educational field training with theoretical lessons such as environmental education field that always need to theoretical learning with workable learning have been in ambiguousness by the way of distance education method and educational technology ( hardware, software ,printed or unprinted, electrician or un electrician, radiant or un radiant ) and educational media that include the standard medias (visual, auditory) and intermediary (educational signs, chart, poster, symptom) and 3-D medias (modle, maqutle, cut).

\section{Distance Education}

Over the past two decades, a number of words to define a new approach to learning and teaching based technologies have been employed. Although distance learning has been applied to the same umbrella, among other terms are also used. Some of them are: learning by telephone, virtual learning, e-learnin, open learning, computer-mediated learning, computer-assisted learning or asynchronous learning,network ${ }^{[4]}$.

Distance education has been seperated from the other kinds of education with Distance word. This word in English-Persion dictionary of Arian par had meaned make,distance,remoteness ,farness and in Haim dictionary it means distance and apace . so the main meaning of this word is distance . Distance education can explain the group of educational activities and apecial programs. Distance education system has different distance . one of its characteristic is physical sepration of teacher and student, but with the use of new technology and communication industry try to fill this sepration. In this method of education, the origin of self study (learner chiefdom) and production of printed self study educations materials have the highest importance. Beside these self study educational materials you can use some others educational tools and educational aid such as radio ,tv, video, satelliteAz a whole, distance education is a kind of learning that happen just because of different technology specialy electronic communication in different places and times. Cooper believed that distance education is a group of educational activities that is performed with the use of electronic tools such as vocal, pictorial, computer and net work ${ }^{[5]}$.

Mayer had a special explanation about virtual and electronical education and named it as an active and smart education that instead of improvement in learning procedure, had a basic and essential role in development and deepening and consolidate the information and links technology ${ }^{[6] \text {. }}$

The way of exploitation of unface to face education based on medias, refered to the first decade of 1900. At the middle of 20th centry, there were different educational programs and the first permit of academic educational and radio were issued in 1921 that it counted as a first based of crection of electronical or distance education. In 1960 distance education technology changed by the improvement of medias and instead of trusting to the post system, university had registered from their students for educational support with the use of multi medias, beside England and America and other uropian countries and Asia, distance education institute eveloped. In fact distance education has demonstrated that it can improve the learning 20 to 25 percent in comparison to conventional lessons class.

Fizl: (1982) believed that the, most simple meaning of distance education is something that happen out side the institute. Hulem burg (1981) believed that the distance education related to expression of different method of teaching and learning that it doesn't happen as a systematic education and plan , and educational system was preparing it. Pawlowski had defined 5 main goals for electronic education that they were based on ignoring the limitations : geographic, cultural, economical, personal ${ }^{[7]}$.

If we consider an ideal modle for virtual education that the electronic educations are its ubset, learners and educational managers can find alot of achivement and advantages that the most important of these advantages are ability to presentation and learning the education at any time and any where and with out limitation, choosing the ideal contents lessons, benefiting on line education coanselore by the education system, best analysis of education procedure and testing the rate of development of learners. Though some critics count the chalanges and draw backs such as the high price of buying and necessarily technology development, limitation in pertaining to communication and communicative foundation, the complete lack of adaption in presented contents with present needs, shortage of management and over sight skills, decrease and loss the social links skill, most of these shortage and weakness had faded with development and expansion of new technology ${ }^{[8]}$.

The basic method of application of distance education divided to 3 groups:

1)Syncorn or linead virtual education : In this method of virtual education, professors present in the virtual education environment. Therefore in this kind of education, the alive videoes of virtual professor can visit by the learners. And professors can identify the questioner person too, and as result the alive discussion take between them.

The most important tools in syncorn virtual education or lineal are using the alive videoes of conference, use and creat virtual class, alive internetical discussion between professors and students and simulation of alive class with use of same modle.

2)Unsyncorn or un lineal virtual educations: In this method professors are not present in a class and obligatorily there is not any alive or on line connection between the professors. In unsyncorn virtual education 
learners can use the contents of lessons and students ask their questions by virtual education environment. And professors send their answer by the same tools. For example students send their question by the electronical post and professors send their answer by the same way.

Unsyncorn virtual education is presentable with use of some tools such as weblogs, electronical post, creat the discussion group, distance tele conference. This method is not synamic like the last method but it has an advantage and that is repeatable.

3)Combination virtual education: In this modle we use all the tools and suitable technologies for the best combinational education. It is a combination of lineal and unlineal education, it creats a balance among learners and rise the usage of virtual education method. Therefore this method is the way of using virtual education that creats with the use of computer technology and real physical environment and try to use of learning in sight knowlage in the educational plans. It doesn't want to follow a special modle and use one of them or educational tools every where that it needs, it creats the best education. This learning insight knowlage of education, sometimes needs to use face to face tools and the other time just use the computer or internet technology or sometimes we needs their combination. It means that when you use atool you should accept its draw backs but with using this method we can perform extremely combination (10\% face to face, $90 \%$ electronical, and or $25 \%$ face to face and $75 \%$ electronical,...) and it allows you to have a best choice depend on the situation of your organization or educational institule ${ }^{[9]}$.

The most important and communicated research is for Rockwel and his colleagues in 2000, in this sampling 207 professors of scientific group of midost university and 30 managers of 2 different collages had showed that just $26 \%$ of professors had information about the ditails of distance education methods. While about $40 \%$ of them believed that it can improve the quality of education and lead to better learning for students and they should use them together with conventional teaching during next 5 years, also $34 \%$ of these professors didn't accept this method and didn't use it.

The reason of these professors in rejection of this method were necessary environment and suitable basis ${ }^{[10] .}$ In other research reported that the score of students that studied with lineal distance education were $20 \%$ more than the students in a usual classes. Researchers understood that the most students trouble is the way of link and professors competency. Casal (2007) researched about (link and information technology for education and progression ) in America, and considered the effect of information technology in best presentation of distance education by professors and teachers and he suggested some suggestion for removal of basis limitation that we will indicated in the next chapter ${ }^{[11]}$.

Joneidi (2001) had a research as (capability of distance education between members of scientific group) and effective factors had examined by acceptance and use of internet and world wide channel among members of scientific group of Tehran university and Tarbiat modares in Iran.

The results of this research ha showed that the members encouraged the students to use computer for doing their homework and lineal research contents but students faced on some limitation just because of shortage of computers of collage. Mr Yaghoobi(2001) searched about (the study of effective factors on acceptance and use of internet in educational and study of scientific group members and students of promotion of agriculture education) some factors about accepting internet had examined such as adaption, complication, examination and familiarity to English language and at the end they understood that internet has the best effects on doing the education ans study affairs in society. Seifi (2007) had a research, in his thesis of master science as (ability study of distance education by internet in library science field and information science of Azad university ).

He expressed that $70 \%$ of library science and information science groups ha ability and equipment for organization distance period while just $40 \%$ of professors profited by necesserly skills for organizing such these periods.

Mr Mahdizadeh (2008) had other research based on discoveries of university opinion sampling, it emphasised on development of culture and attention to attitudes of distance education and its methods were influenced by professors ideas and teachers and level of knowlage and technical information of details, methods and electronic and distance education tools ${ }^{[12]}$.

\section{Methodology}

In this study has used the descriptive-measurement method or set up according to the goals of research, before the test presented a form to both groups virtual and conventional students. The scores of these forms considered as a previous exam. A pilot group was under education for 10 sessions. At the end of this educational program presented 2 forms again. And the scores of these levels considered for a following exam in analysis. Stimotion of internet similarity for this form stimated by shifer according to halved constancy factor for both groups, and had reported 0/81 and 0/75 orderly. In this research has used Kronbakh Alpha factor for studing of constancy of forms. After putting the scores, total Kronbakh Akpha factor was equal 0/741. This study did on all the end semester students of Payam noor university in 2011-2012 A class was virtual group (30 members) and 
the other class as conventional group (30 members) that were chosen 60 members as mass of statistic sample in society.

\section{Analysis}

The use of SPSS software counted the charts of abundance distribution responders in previous exam and following exam, according to amount of correct or wrong answers.

In chart deal with survey statistic information related to age of students. According to chart the avarage of age between 60 students was 24.85 and deviation of age was equal 4.61. Also, the youngest person in this study was 21 and the oldest person was 37 . And most of the students were 6 .

TABLE 1. Useful describers related to the age of students

\begin{tabular}{cccccc}
\hline Varialbe & Armies & Number & Mean \pm SD & Test & P value \\
\hline \multirow{2}{*}{ Awareness } & Vivtual & 30 & $10 / 88 \pm 2 / 29$ & $\mathrm{~T}=3 / 045$ & $0 / 004$ \\
& Traditional & 30 & $8 / 85 \pm 2 / 61$ & & \\
\hline
\end{tabular}

As you can see in chart $2, \mathrm{~T}=-0 / 39$ and $\mathrm{P}=0 / 693$ and in humanities for analysis of discoveries or $\mathrm{P}=0 / 05$ that we can understand that the avarage of age is not meaning full difference between these 2 groups.

You can see chart3, $\mathrm{T}=3 / 045$ and $\mathrm{P}=0 / 004$ and the avarage of virtual students exam scores is $=10 / 88$ and the avarage of conventional students exam score is $=8 / 85$ and according to $\mathrm{P}=0 / 05$, we can understand the significant difference between 2 groups. The avarage of awareness of virtual students are more than conventional students.

TABLE 2. Traits describers related to the age of students

\begin{tabular}{ccccc}
\hline Varialbe & Armies & Mean \pm SD & Test & P value \\
\cline { 2 - 4 } Age & Vivtual & $55 / 10 \pm 38 / 93$ & T=-0/39 & $0 / 693$ \\
& Traditional & $65 / 15 \pm 37 / 40$ & & \\
\hline
\end{tabular}

TABLE 3. Comparison of exams score in 2groups of virtual and conventional education

\begin{tabular}{|c|c|c|c|c|c|c|c|}
\hline $\begin{array}{c}\text { Integer } \\
\text { values } \\
\end{array}$ & Missing & Mean & Mode & Std/Deviation & Variance & Maximum & $\begin{array}{c}\text { Minim } \\
\text { um }\end{array}$ \\
\hline 21 & 3 & $85 / 24$ & 26 & $4 / 61$ & $33 / 73$ & 37 & 21 \\
\hline
\end{tabular}

\section{CONCLUSION}

According to the researches, use of distance education systems in connection world is a force not a choice, according to new achievement and deletion of snags and present educational problems, so we should use the virtual education method with suitable tools improving the qualities of educational unit and survey of creature of that group based on limitations and facitities. And also standardize of contents and educational containers in virtual education discussion are very important, that specially universities should consider. In creation of virtual educations should consider the effective factors in creat and enduring too. It is obvious that that basic investment for virtual education is move than routine price of periods but incomparisson with basic investment for creating of necessory space in face to face education in very low ${ }^{[13] .}$

As in chart 2 and 3 have showed some students who have trained distance education of procurement and production of materials and progressive tools, environment education field by distance education method and by educational film or educational medias by distance education system in first semester of 2011-2012, the average of virtual students score were $=10 / 88$ and conventional students were $=8 / 85$ and according to $\mathrm{P}=0 / 05$, we can understand that there is a coaspicuous difference between these 2 groups. Research s discoveries are same as Farahani discoveries (1997), Estinsoon and Estenbrouy (1998) and Kshavarz (2002) is consistent.

There fore in this study for training of procurement and production of materials and progressive tools lesson about environmental education in environmental education field used from distance education method with use of educational medias, It means that in this research, the use of distance education system and educational medias changed the educational role of professor and instead of being the professor in the workable class and having face to face education. It transfered her/his educational methods by film and educational methods to students. This method helped to students to watch the related skills and they can stop the film in the required time and analysis it in different levels and take help from this ability for more learning. It means that in this study in spite of changes in educational methods from face to face education to virtual education. Change of the role of professors in education, decrease of facing with professor and student, indirect education of 
professor, decrease of presence of students in class, cause to increase the educational quality, Different education system with educational aid of visual have ability for presence of lesson and production of materials and progressive tools in environment education field, and this educational methods have the ability of generality in other lessons. And according to development of technology and with combination of medias and appearance of more progressive medias, thid educational method can be suitable supplementary for face to face education and professor chiefdom in distance education system.

\section{REFERENCES}

[1] Garrison, D. and R. Anderson, Terry. (2005). e-Learning in the 21st Century theoretical and practical, (Translated by E. and S. Safai unitary Zvarky Zarei), Tehran: Science and Technology Press.

[2] Arabani, Dana (2006). images of groups of experiences on the Internet, Proceedings of distance education, Tehran: Institute of distance.

[3] Bowen, b,e. and Thomsom. J. (1995). Distance education needs of agribusinesses and professional agriculture associations. Journal of $36(4): 18-25$.

[4] Ali Abadi, Khadijah. (2001). Virtual university and distance education, Proceedings of the conference on educational technology in higher education, university, arak Reference 5.

[5] Cooper, R. (2004). E-learning in the World. London: Falmer.

[6] Mayer, R. (2005). IT for Education:Oxford.

[7] Pawlowski, T. (2006). Information Technology and Education. Leeds: Kork 5.

[8] Iravani, H. (2005). the individual's identity - center of Virtual Learning Environments, Learning Conference of the Virtual University, South Tehran Branch, Islamic Azad University Research Council.

[9] Report of virtual universities and e-learning systems (2002).Center for Advanced Communications and Information Technology, Sharif University of Technology.

[10] Rockwell, S.K., Schauer, J., Fritz, S.M. , \& Marx, D.B. (2000). Faculty education, assistance, and support needed to deliver education via distance. On-line Journal of Distance Education Administration, 3(2).

[11] Sarmadi.M and Soltani, M. (2003).Proceedings of distance education), second edition), Tehran: Payam Noor University Press.

[12] Yakhobi, J. (2001). Factors affecting the acceptance and use of the Internet in teaching and research activities of faculty and graduate students to promote agriculture, Journal of Agricultural Sciences, Iran.

[13] Saifi, L. (2007). the feasibility of distance education via the Internet in the field of LIS Azad University, Tehran, Faculty of Humanities, Islamic Azad University, Science \& Research, LIS master's thesis.

[14] Joneidi, M. (2001).faculty competencies in distance education, distance learning conference. Proceedings of the University. 